\title{
A case of esophageal Crohn's disease resistant to corticosteroids but responsive to cyclosporine $\mathrm{A}$
}

PL BECK, TE LAY. A case of esophageal Crohn's disease resistant to corticosteroids but responsive to cyclosporine A. Can J Gastroenterol 1996;10(3):153-155. Esophageal ulceration is a rare and potentially devastating complication of Crohn's disease (CD). A 29-year-old male with odynophagia is described. He had no prior history of inflammatory bowel disease, connective tissue disorder or rheumatological disease. He denied symptoms of a recent viral infection and did not have significant human immunodeficiency virus risk factors. He did not have eye, skin, oral or genital lesions. Omeprazole failed to control his symptoms. On endoscopy, large esophageal ulcerations were noted. Biopsies showed active chronic inflammation with granulomatoid changes. Autoimmune, viral and acid-fast bacilli studies were normal. The odynophagia failed to improve, and he subsequently developed right lower quadrant pain and hematochezia. Colonoscopy demonstrated extensive hemorrhagic ileal ulcers, and biopsies were suggestive of CD. The odynophagia did not respond to high dose intravenous steroids and bowel rest. The patient was reluctant to take cytotoxic agents, and thus a course of cyclosporine A was initiated. The patient responded rapidly and was able to tolerate a full diet within $48 \mathrm{~h}$. Repeat gastroscopy was normal. To the authors' knowledge, this is the first reported case of esophageal CD treated with cyclosporine A.

Key Words: Crohn's disease, Cyclosporine, Esophageal

\section{Maladie de Crohn oesophagienne résistante aux corticostéroïdes, mais non la cyclosporine $\mathrm{A}$}

RÉSUMÉ : L'ulcère de l'oesophage est une complication rare mais potentiellement dévastatrice de la maladie de Crohn. Le cas d'un patient de 29 ans atteint d'odynophagie est décrit ici. Ses antécédents comprenaient maladie inflammatoire de l'intestin, maladie des tissus conjonctifs ou maladie rhumatologique. Ne présentait aucun symptôme d'infection virale récente ni facteur de risque particuliers à l'égard du virus de l'immunodéficience humaine. Il ne présentait aucune lésion oculaire, cutanée, orale ou génitale. L'oméprazole a échoué à maîtriser ses symptômes. À l'endoscopie, de grandes ulcérations oesophagiennes ont été notées. Les biopsies ont révélé une inflammation chronique active avec altération granulomatoïde. Les épreuves visant l'identification de bacilles auto-immunitaires viraux et résistants à l'acide se sont révélées normales. L'odynophagie ne s'est pas améliorée et le patient a par la suite développé une douleur au quadrant inférieur droit et évacué des selles sanglantes. La coloscopie a permis de confirmer la présence d'ulcères iléo-hémorragiques étendus et les biopsies concordaient avec la maladie de Crohn. L'odynophagie n'a pas répondu à des doses élevées de corticostéroïdes par voie i.v. ni à la mise au repos de l'intestin. Le patient était réticent à prendre des agents cytotoxiques, un traitement par cyclosporine $\mathrm{A}$ a donc été instauré. Le patient a répondu rapidement et tolérait une alimentation normale après 48 heures. Une nouvelle gastroscopie s'est révélée normale. À la connaissance des auteurs, il s'agit du premier cas rapporté de maladie de Crohn de l'oesophage justiciable de la cyclosporine A.

Department of Medicine, Foothills Hospital, Calgary, Alberta

Correspondence and reprints: Dr Paul L Beck, Department of Medicine, Foothills Hospital, 1403-29th Street NW, Calgary, Alberta T2N

2T9. Telephone 403-220-6536, fax 403-270-0995

Received for publication March 31, 1995. Accepted August 13, 1995 


\section{PAUL L BECK MD PhD, THOMAS E LAY MD}

$E_{\mathrm{b}}^{\mathrm{s}}$ sophageal ulceration in Crohn's disease (CD) is a rare but potentially devastating complication. Ulceration of the esophagus has been described in both ulcerative colitis (UC) and, more commonly, CD $(1,2)$. The incidence of esophageal involvement in $\mathrm{CD}$ has been reported to be as high as $1.8 \%$ in adults with $\mathrm{CD}(2)$ and up to $6.5 \%$ in the pediatric $\mathrm{CD}$ population (3). There are only three cases in the literature that describe patients who have had odynophagia due to esophageal ulcerations as the initial presenting symptom of CD (4-6). Several other disease states can be associated with esophageal ulcerations, including UC, human immunodeficiency virus seroconversion syndrome, Behçet's disease and infections due to cytomegalovirus, herpes simplex virus, amoebiasis, and Candida and Yersinia species. These conditions must be ruled out before making the diagnosis of CD $(1,6-8)$.

\section{CASE PRESENTATION}

A 29-year-old Caucasian male presented with a twomonth history of odynophagia with both liquids and solids. He had no other symptoms at presentation and specifically denied symptoms of a recent viral infection and of rheumatological, connective tissue, neurological, gastrointestinal, pulmonary and cardiac disease. He denied eye, skin, oral or genital lesions. Past medical history was negative. He denied homosexual contact, multiple sex partners and intravenous drug use. He rarely drank alcohol and did not smoke. His family's medical history was also negative.

Physical examination was completely normal with no oral ulcers, and no signs of ophthalmological, dermatological, gastrointestinal, rheumatological, neurological, cardiac or pulmonary disease. He failed to respond to oral omeprazole ( $40 \mathrm{mg} /$ day), and on gastroscopy multiple deep ulcers were noted in the distal esophagus. Biopsies of the esophageal lesions revealed severe active, chronic inflammation with a granulomatoid reaction that extended through the entire depth of the biopsies (Figure 1). No giant cells were noted. Viral, acid-fast bacilli and fungal studies were all normal.

Initial blood work, including electrolyte panel, complete blood count and liver function studies, was normal. Serology for syphilis and acquired immunodeficiency syndrome was negative. Antinuclear antibody titres and complement levels were normal.

An upper gastrointestinal and small bowel followthrough were done and showed nonspecific changes in the ileum. A course of oral prednisone $(60 \mathrm{mg} /$ day $)$ failed to relieve the symptoms, and he then developed right lower quadrant pain and hematochezia. Large bleeding ulcers and cobblestoning of the terminal ileum were noted on colonoscopy. Biopsies showed chronic inflammatory changes consistent with CD. Gastroscopy showed progression of the

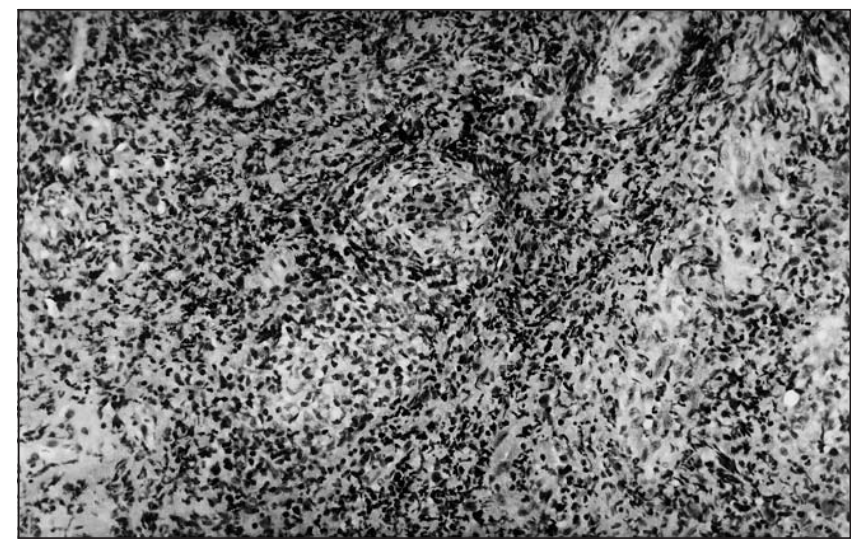

Figure 1) Granulomatoid reaction in the submucosa underlying an esophageal ulcer. Note the collections of histiocytes surrounded by an inflammatory cell infiltrate of predominantly neutrophils, macrophages and lymphocytes ( $x 150)$

esophageal ulcers and cobblestoning was noted in the distal esophagus. He was then started on $100 \mathrm{mg}$ hydrocortisone intravenously tid and total parenteral nutrition. There was little improvement over 14 days, and repeat endoscopy showed little change in the esophageal lesions.

Treatment options were discussed with the patient. Due to his concerns about cytotoxic agents and his desire to obtain rapid clinical improvement, he was started on oral cyclosporine A $300 \mathrm{mg}$ bid $(9.2 \mathrm{mg} / \mathrm{kg} /$ day $)$. Within $48 \mathrm{~h}$ of starting the cyclosporine his symptoms dramatically improved and he was able to tolerate a full diet. A cyclosporine level of $280 \mathrm{~g} / \mathrm{L}$ was noted at the dose of $300 \mathrm{mg}$ bid by mouth (therapeutic levels of 250 to $450 \mathrm{~g} / \mathrm{L}$ ). The cyclosporine was tapered over four months, and repeat gastroscopy showed no signs of esophageal inflammation, macroscopically or on biopsy.

The patient has been followed for 31 months. Cyclosporine therapy (100 mg bid by mouth for 14 days) was reinstituted twice for symptomatic relapses that occurred during the initial eight months of follow-up. He has been free from symptoms since the last course of therapy almost 22 months ago. Unfortunately the patient refused to have blood work during these two courses of therapy and thus cyclosporine levels were not obtained. A normal complete blood count and serum creatinine were noted approximately one month following the last course of cyclosporine. His blood pressure has remained within normal ranges and he has not noted any other side effects from the cyclosporine therapy.

\section{DISCUSSION}

The diagnosis of $\mathrm{CD}$ of the esophagus is often difficult because rarely are granuloma and/or giant cells noted on biopsy (less than 25\% of the time) (2). However, in the case presented, the granulomatoid inflammation of the esophagus, the development of severe ileal disease and the lack of features of rheumatological and connective tissue diseases strongly support the diagnosis of esophageal CD.

Esophageal involvement in Behçet's disease is rare; however, approximately $40 \%$ of these patients have coexisting 
ileocolonic disease (8). The patient in the present report did not have oral ulcers, erythema nodosum, thrombophlebitis, folliculitis, iridocyclitis, chorioretinitis or genital ulcers, of which any three constitute the major diagnostic criteria of Behçet's disease (9).

Oral ulcers have been reported to be associated with CD of the upper gastrointestinal tract in both adult and pediatric populations (3). In one study, six of nine adults with esophageal CD had oral ulcers, and it was suggested that oral ulcers in CD are an indication for endoscopy (2).

Esophageal ulcers in CD usually respond rapidly to corticosteroids and rarely relapse $(3,6)$. One case has been described of a patient with esophageal CD that rapidly responded to corticosteroids, yet who later had two episodes of relapse that responded well to reinstitution of the steroids (10). There has never been a reported case of esophageal CD unresponsive to corticosteroids, but there have only been approximately 60 cases of esophageal ulcers in $\mathrm{CD}$ reported in the literature (6). Failure of esophageal CD to respond to

to treat. Thus, it is essential to treat and follow patients with esophageal CD aggressively. These patients usually respond to corticosteroids. However, this case illustrates that cyclosporine A may represent a rapid and effective therapy for patients who fail traditional therapy.

ACKNOWLEDGEMENTS: The authors thank the pathologists who reviewed this case: Drs IH Jadusingh, MA Andersen, V Chang-Poon, and JK Kelly.

\section{REFERENCES}

1. Rosendorf C, Grieve WT. Ulcerative oesophagitis in association with ulcerative colitis. Gut 1967;8:344-7.

2. Geboes K, Janssens J, Rutgeers P, Vantrappen G. Crohn's disease of the esophagus. Clin Gastroenterol 1986;8:31-7.

3. Lenaents C, Roy CC, Vaillancourt M, Weber AM, Morin CL, Seidman E. High incidence of upper gastrointestinal tract involvement in children with Crohn's disease. Pediatrics 1989;83:777-81.

4. LiVolsi VA, Jaretzki A. Granulomatous esophagitis. A case of Crohn's disease limited to the esophagus. Gastroenterology 1973;64:313-9.

5. Ghahremani GG, Gore RM, Breuer RI, Larson RH. Esophageal manifestations of Crohn's disease. Gastrointest Radiol 1982;7:199-203.
$\mathrm{H}_{2}$ blockers and omeprazole has been described previously $(2,6)$.

Use of cyclosporine in $\mathrm{CD}$ of the upper gastrointestinal tract has not been previously described. Cyclosporine 7.6 to $10 \mathrm{mg} / \mathrm{kg} /$ day has been effective in the treatment of corticosteroid-resistant CD involving the large and small bowel and CD-related fistula $(11,12)$. However, lower doses of cyclosporine $(2.5 \mathrm{mg} / \mathrm{kg} /$ day $)$ have not been found to be effective (13).

Patients with UC have been shown to respond rapidly to cyclosporine therapy (14). Cyclosporine has also been found effective in treating rheumatoid arthritis and Behçet's disease $(9,15)$. Specifically, cyclosporine has been found to be effective in treating oral ulcerations in Behçet's disease (9). It has not been tried in the treatment of esophageal Behçet's disease. Again, the patient in the present study did not have any of the major diagnostic criteria required for the diagnosis of Behçet's disease.

The complications of esophageal CD include stricture and fistula formation and are often devastating and difficult

6. Beck PL, Blustein PK, Andersen MA. Aphthous esophageal ulceration: A novel presentation of Crohn's disease? Can J Gastroenterol 1994;8:101-4.

7. Rabeneck L, Boyko WJ, McLean DM, McLeod WA, Wong KK. Unusual esophageal ulcers containing enveloped viruslike particle in homosexual men. Gastroenterology 1986;90:1882-9.

8. Mori S, Yoshihira A, Kawamura H, Takeuchi A, Hashimoto T, Inaba G. Esophageal involvement in Behçet's disease. Am J Gastroenterol 1983;78:548-53.

9. Masuda K, Urayama A, Kogure M, et al. Double-masked trial of cyclosporin versus colchicine and long-term open study of cyclosporin in Behçet's disease. Lancet 1989;i:1093-6.

10. Fernandez CM, Ledo L, Cunqueiro R, et al. Early esophageal Crohn's disease: an endoscopic view. Gastrointest Radiol 1990;36:303-4.

11. Brynskov J, Freund L, Rasmussen SN, et al. A placebo-controlled, double-blind, randomized trial of cyclosporin therapy in active chronic Crohn's disease. N Engl J Med 1989;321:845-50.

12. Hanauer SB, Smith MB. Rapid closure of Crohn's disease fistulas with continuous intravenous cyclosporin A. Am J Gastroenterol 1993;88:646-9.

13. Feagan BG, McDonald JWD, Rochon J, et al. Low-dose cyclosporine for the treatment of Crohn's disease. N Engl J Med 1994;330:1846-51.

14. Lichtiger S, Present DH, Kornbluth AK, et al. Cyclosporine in severe ulcerative colitis refractory to steroid therapy. N Engl J Med 1994;330:1841-5.

15. Tugwell P, Bombardier C, Gent M, et al. Low-dose cyclosporin versus placebo in patients with rheumatoid arthritis. Lancet 1990;335:1051-5. 


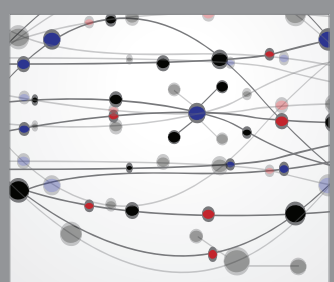

The Scientific World Journal


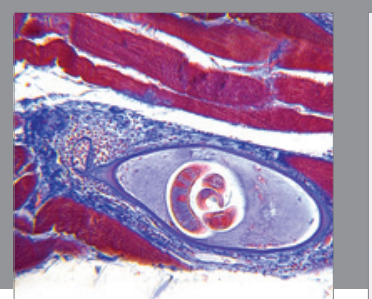

Gastroenterology Research and Practice

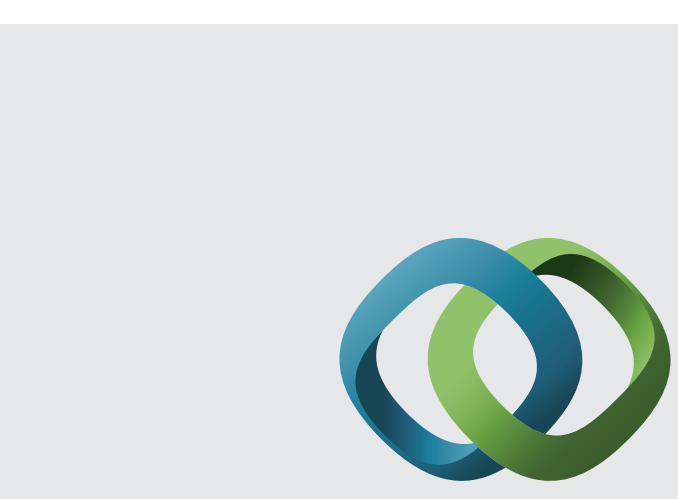

\section{Hindawi}

Submit your manuscripts at

http://www.hindawi.com
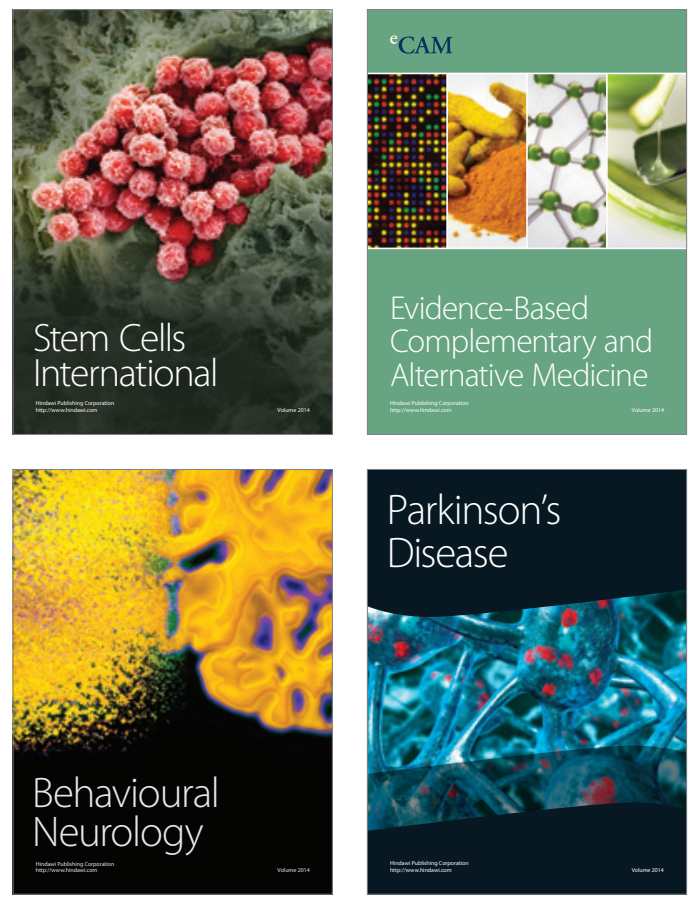
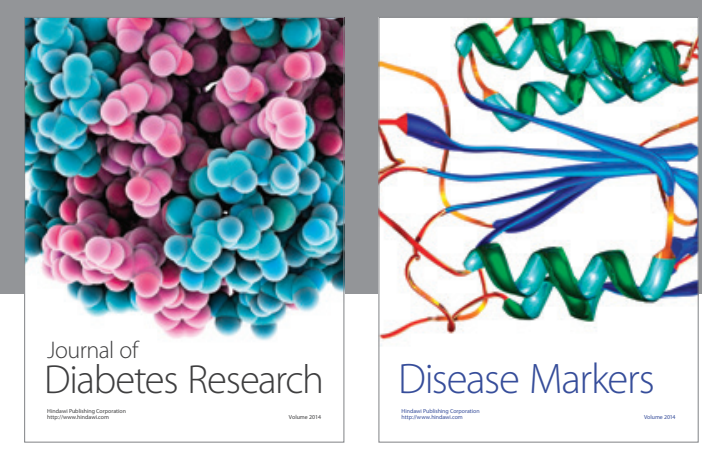

Disease Markers
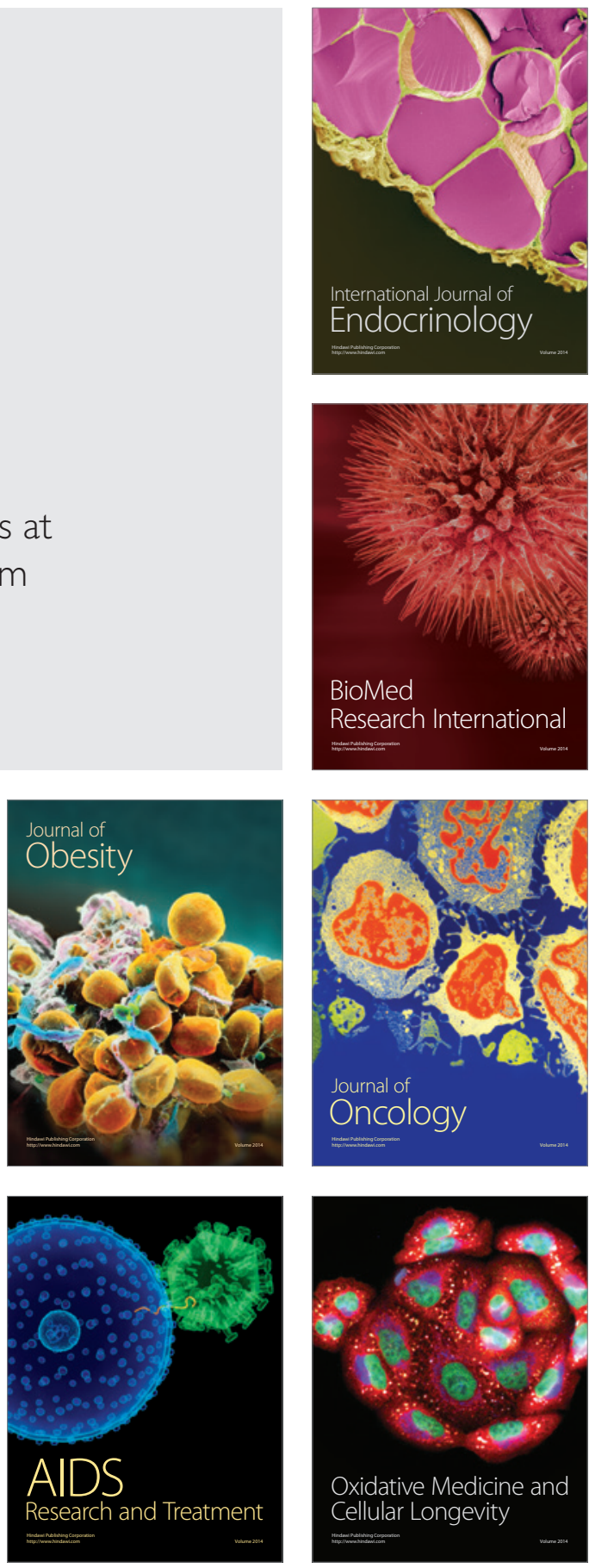